\title{
Immune Architecture of Colorectal Lung Metastases and Implications for Patient Survival
}

\author{
Stefan M. Brunner ${ }^{a} \quad$ Ulrich Hahn ${ }^{a}$ Tonia Jeiter ${ }^{a}$ Rebecca Kesselring ${ }^{a}$ \\ Christoph Rubner $^{a} \quad$ Petra Ruemmele $^{b} \quad$ Zsolt Sziklavarie \\ Hans S. Hofmann ${ }^{d}$ Hans J. Schlitt ${ }^{a}$ Stefan Fichtner-Feigla, c \\ ${ }^{a}$ Department of Surgery, ${ }^{b}$ Institute of Pathology, ${ }^{c}$ Regensburg Center of Interventional \\ Immunology, and d Department of Thoracic Surgery, University Medical Center Regensburg,

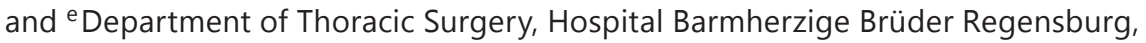 \\ Regensburg, Germany
}

\section{Key Words}

Immune infiltrate $\cdot$ Tumor microenvironment $\cdot$ Cellular infiltration · Prognostic parameters

\begin{abstract}
Background: Pulmonary metastases occur in $10-20 \%$ of patients with colorectal cancer and significantly influence long-term survival. In this study, the immunological architecture of colorectal lung in comparison to liver metastases and its impact on patient survival were examined. Methods: Specimens of patients with colorectal lung and liver metastases were stained for HE, CD4, CD8, CD20, CD68 and CD45RO. Besides histomorphological evaluation, immunohistochemical stainings were analyzed for the respective cell numbers separately for tumor area, infiltrative margin and distant lung or liver stroma. These findings were correlated with clinical data and patient outcome. Results: In colorectal lung $(n=69)$ in comparison to liver ( $n=222)$ metastases, the immunological focus is located in the tumor region. A high $\mathrm{CD} 4^{+}$cell infiltration of this area is associated with prolonged survival of patients after resection of colorectal lung metastases [103 \pm 33 (high) vs. $37 \pm 6$ months (low); $p=0.0246]$. Patients who were treated with preoperative chemotherapy did not show differences in immune infiltrates compared to chemotherapy-naïve patients. Conclusion: Colorectal lung and liver metastases showed a distinct immunological architecture. A dense cell infiltration of colorectal lung metastases by $\mathrm{CD} 4^{+}$cells was related to prolonged patient survival. Preoperative chemotherapy did not influence cellular immune infiltrates.

(c) 2016 S. Karger AG, Basel
\end{abstract}


Brunner et al.: Immune Architecture of Colorectal Lung Metastases and Implications for Patient Survival

\section{Introduction}

Therapy decisions in patients with primary colorectal carcinomas are currently made according to guidelines based on the UICC/AJCC TNM system that stages these tumors by the extent of wall infiltration of resected tissue and the presence of metastases [1]. To explain considerable outcome variations of patients staged in the same histological category, the immunological tumor microenvironment and its effect on patient outcome have been extensively investigated [2-6]. These studies of primary colorectal carcinomas have demonstrated beneficial survival effects of tumor infiltration by $\mathrm{CD} 4^{+} \mathrm{Th} 1, \mathrm{CD}^{+}$cytotoxic and $\mathrm{CD} 45 \mathrm{RO} \mathrm{O}^{+}$ memory T cells, whereas Th17 cell infiltration is associated with poor patient survival [7-9]. Based on these new results, immune scores have been developed to prognosticate patient survival, which have been proposed as a new component for classification of primary colorectal carcinoma [10]. In addition to these scores, our group investigated colorectal liver metastases, which occur in $40-50 \%$ of patients with colorectal cancer and determine longterm survival, in order to elucidate their immune architecture [3]. In this study, we demonstrated that peritumoral infiltration of $\mathrm{CD} 45 \mathrm{RO}^{+}$cells and a fibrotic capsule containing the liver metastases were independent prognosticators for prolonged survival of patients with colorectal liver metastases [3]. Based on these two factors, we developed a cellular immune score to stratify patients according to prognosis, which can be included in the proposed immune scoring concepts [3]. Not only liver metastases, but also pulmonary metastases, which occur in $10-20 \%$ of patients, limit the prognosis of patients with colorectal carcinoma $[11,12]$. Despite the fact that pulmonary metastases are the most frequent extraabdominal site of colorectal metastasis, studies that investigated their immune infiltrate are lacking so far [13]. To address this problem, this study elucidated the immunological tumor microenvironment of pulmonary metastases of colorectal carcinoma under the hypothesis that a distinct immune architecture is associated with prolonged patient survival. We further aimed to elaborate differences between immune infiltrates of colorectal liver and lung metastases.

\section{Methods}

Patient Selection and Data Collection

This study was performed at the University Medical Center of Regensburg, Germany, and was approved by the local ethics committee (No. 12-101-0009). Patients with colorectal lung metastases (confirmed by histology) who underwent pulmonary surgery at the University Medical Center of Regensburg or at the teaching hospital Barmherzige Brüder Regensburg between 2004 and 2010 were identified using the hospital computer database. For comparison of immune infiltrates, patients with colorectal liver metastases (confirmed by histology) who underwent liver surgery at the University Medical Center of Regensburg between 2004 and 2010 were identified using the hospital computer database. Only patients receiving primary lung resection with curative intent were included (achieved in $97.1 \%$ of pulmonary resections). In case of multiple lung metastases, the largest was used for analysis. General patient information, TNM classification of primary tumors and histological data on colorectal lung and liver metastases were obtained from the routine pathology report. If patients had received chemotherapy within 3 months prior to lung resection, this was assessed as 'preoperative chemotherapy'. This included patients that received chemotherapy for pulmonary metastases, for synchronous pulmonary and liver metastases and for the primary tumor. The period of 3 months was chosen to investigate chemotherapeutical effects on immune infiltrates, which would be expected to be much smaller in case of longer time periods accounted for 'preoperative' chemotherapy. Survival data were collected using the database of the Tumorzentrum Regensburg (regional tumor center of East Bavaria), Germany.

Histological Analysis

Tissue cross sections were stained for CD4, CD8, CD45RO, CD20 and CD68 (described in detail in online suppl. materials; for all online suppl. material, see www.karger.com/doi/10.1159/000447555). Digital 
Table 1. Clinical characteristics of patients with colorectal lung metastases

\begin{tabular}{|c|c|c|}
\hline & Yes & No \\
\hline Male & $45(65.2)$ & $24(34.8)$ \\
\hline Nicotine abuse & $13(18.8)$ & $56(81.2)$ \\
\hline Pulmonary disease & $9(13.0)$ & $60(87.0)$ \\
\hline Synchronous lung metastases & $6(8.7)$ & $63(91.3)$ \\
\hline Singular lung metastases & $43(62.3)$ & $26(37.7)$ \\
\hline R0 resection of lung metastases & $67(97.1)$ & $2(2.9)$ \\
\hline Lymphadenectomy & $48(69.6)$ & $21(30.4)$ \\
\hline Pulmonary lymph nodes positive (out of lymphadenectomy) ${ }^{\mathrm{a}}$ & 8 (16.7) & $40(83.3)$ \\
\hline Neoadjuvant chemotherapy prior to resection of lung metastases & $12(17.4)$ & $57(82.6)$ \\
\hline Adjuvant chemotherapy after resection of lung metastases & $18(26.1)$ & $51(73.9)$ \\
\hline Primary tumor colon/rectum & $23(33.3)$ & $46(66.7)$ \\
\hline Primary tumor lymph node metastases & $36(52.2)$ & $33(47.8)$ \\
\hline Synchronous liver metastases & $3(4.3)$ & $66(95.7)$ \\
\hline Primary tumor $\mathrm{G} 2 / \mathrm{G}^{\mathrm{b}}$ & $48(80.0)$ & $12(20.0)$ \\
\hline Primary tumor $\mathrm{R} 0^{\mathrm{b}}$ & $54(91.5)$ & $5(8.5)$ \\
\hline
\end{tabular}

Data are presented as $n(\%) .{ }^{\text {a }}$ Only performed in 48 patients. ${ }^{b}$ Some histology reports of primary tumors incomplete.

images of lung and liver metastases were obtained at $\times 20$ magnification on light microscopy (Carl Zeiss MicroImaging GmbH, Jena, Germany).

The numbers of $\mathrm{CD}^{+}, \mathrm{CD}^{+}, \mathrm{CD} 45 \mathrm{RO}^{+}, \mathrm{CD} 20^{+}$and $\mathrm{CD} 68^{+}$cells were manually counted in 3 randomly selected areas (×20 magnification) using Image 1.45 s software (Wayne Rasband, National Institutes of Health, USA; example in online suppl. materials) and the mean was taken separately for tumor region (Tu), infiltrative margin (Im) and distant stroma (Sd). Im was defined as the area within one field of view $(\times 20)$ next to the tumor, and $S d$ was defined as outmost area of the specimen in a region that was tumor free.

For survival analyses, patients were divided into two groups depending on the numbers of $\mathrm{CD} 4^{+}, \mathrm{CD} 20^{+}$, $\mathrm{CD} 45 \mathrm{RO}^{+}, \mathrm{CD}^{+} 8^{+}$and $\mathrm{CD}^{+}$cells in the different areas. Cell numbers larger than the respective mean were defined as 'high', smaller as 'low'.

\section{Statistical Analysis}

Kaplan-Meier graphs were calculated for overall survival analyses. Group comparisons were made using the log-rank test. Patient data are presented as median with interquartile range (IQR) or as number with percentages. To evaluate correlations, Pearson's correlation, and for continuous variables the MannWhitney test was used. The level of significance was set at $p<0.05$. All histological evaluations were performed independently in a blinded fashion by 2 examiners (S.M.B., U.H.). In case of divergent evaluation, consensus was achieved reevaluating the cross sections together. To explore reproducibility after some time, random samples were drawn and reevaluated. In all histological evaluations, the concordance rate between the observers and the reproducibility of the results was $>95 \%$.

\section{Results}

\section{Patient Characteristics}

A total of 69 patients ( 24 female, 35\%; 45 male, 65\%) with colorectal lung metastases with a median age of 64 years (IQR 57-71) were enrolled. For detailed information on patient characteristics, see table 1. Overall median survival time was 33 months (IQR 17-56) after lung surgery with a 3 -year survival rate of $44 \%$. The immune infiltrates of these patients with lung metastases were compared with a collective of 222 patients (83 female, 41\%; 118 male, 59\%) with a median age of 62 years (IQR 53-68) after resection of colorectal liver metastases [3]. 


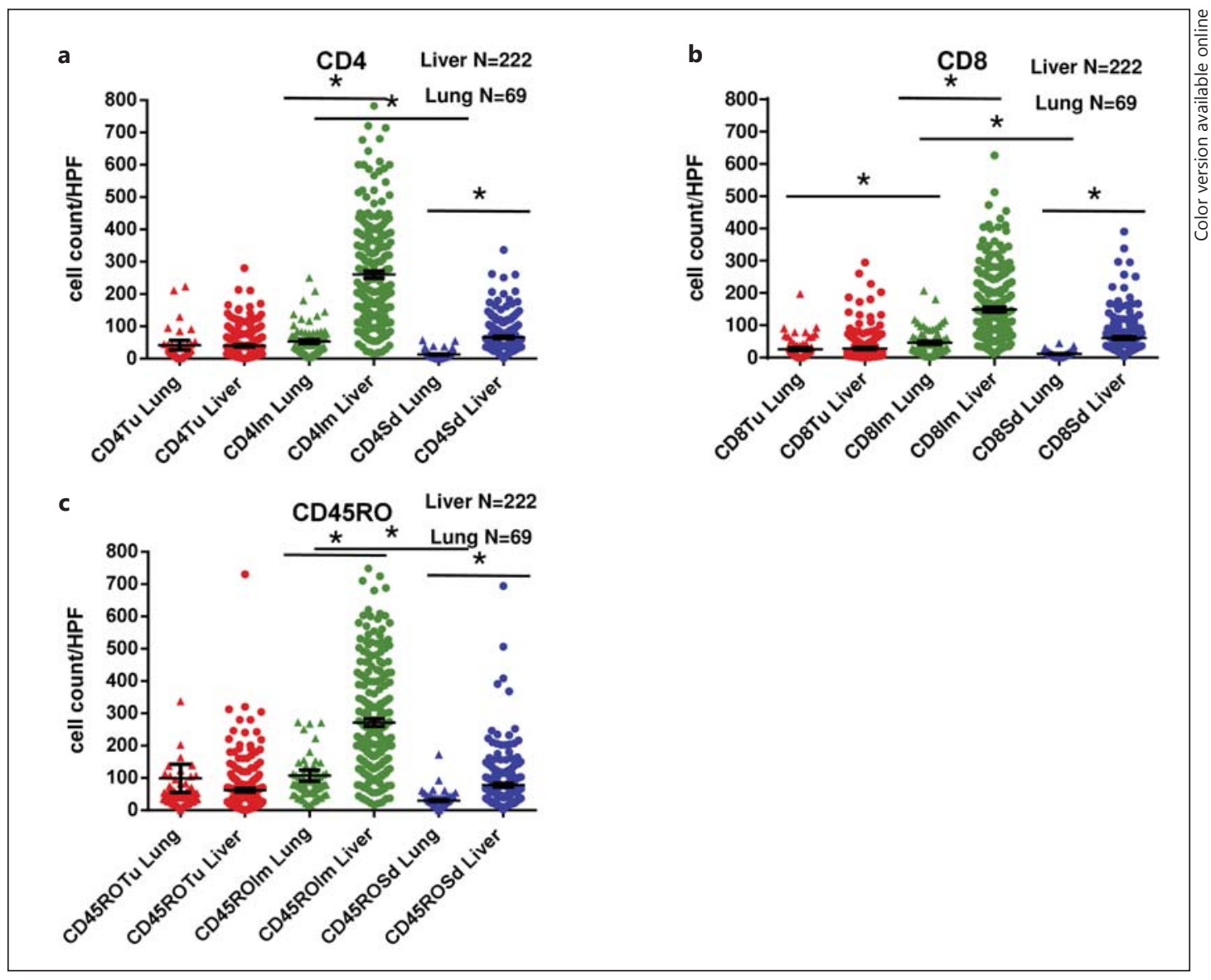

Fig. 1. Cellular infiltration of colorectal lung in comparison to colorectal liver metastases. a Infiltration by $\mathrm{CD}^{+}$cells in the Tu of the liver and lung was comparable (liver $40 \pm 3$ vs. lung $42 \pm 15$ cells $/ \mathrm{HPF}$; $\mathrm{p}=0.8408$ ), whereas in the Im (liver $261 \pm 11$ vs. lung $54 \pm 6$ cells/HPF; $p<0.0001$ ) and Sd (liver $66 \pm 4$ vs. lung $13 \pm 2$ cells/HPF; $\mathrm{p}<0.0001$ ) regions, liver samples showed significantly higher $\mathrm{CD}^{+}$cell numbers. $\mathbf{b}$ Infiltration by $\mathrm{CD}^{+}$cells in the Tu was similar in the liver and lung samples (liver $28 \pm 3$ vs. lung $26 \pm 4$ cells/HPF; $p=$ 0.6856 ), with significantly higher cell numbers in the liver compared to the lung tissue in the Im (liver $149 \pm$ 7 vs. lung $46 \pm 5$ cells/HPF; $\mathrm{p}<0.0001$ ) and Sd (liver $61 \pm 4$ vs. lung $11 \pm 1$ cells/HPF; $\mathrm{p}<0.0001$ ) regions. c Infiltration by $\mathrm{CD}_{4} 5 \mathrm{RO}^{+}$cells in the Tu was comparable in the liver and lung samples (liver $62 \pm 5 \mathrm{vs}$. lung $99 \pm 43$ cells/HPF; $p=0.1561$ ), whereas the cell numbers of liver samples were significantly higher in the Im (liver $272 \pm 11$ vs. lung $107 \pm 17$ cells/HPF; $\mathrm{p}<0.0001$ ) and Sd (liver $78 \pm 6$ vs. lung $30 \pm 3$ cells/HPF; $p<$ 0.0001 ) regions. $* \mathrm{p}<0.05$.

\section{Cellular Immune Infiltration Pattern Is Different in Colorectal Lung Compared to Liver Metastases}

Cellular immune infiltration was analyzed separately for Tu, Im and Sd in the comparison between colorectal lung and liver metastases. In the $\mathrm{Tu}$, the infiltration by $\mathrm{CD}^{+}$cells was comparable between the liver and lung (liver $40 \pm 3$ vs. lung $42 \pm 15$ cells/HPF; $p=0.8408$ ), whereas in the Im (liver $261 \pm 11$ vs. lung $54 \pm 6$ cells/HPF; $p<0.0001$ ) and also in the Sd (liver $66 \pm 4$ vs. lung $13 \pm 2$ cells/HPF; $p<0.0001$ ), liver samples showed significantly higher $\mathrm{CD}^{+}$cell numbers when compared to lung tissue (fig. 1a). Regarding $\mathrm{CD}^{+}$cells, the $\mathrm{Tu}$ showed a similar cell infiltration in the liver and lung samples (liver $28 \pm 3$ vs. lung $26 \pm 4$ cells/HPF; $p=0.6856$ ), with cell numbers being significantly higher in liver tissue when compared to lung tissue in the Im (liver $149 \pm 7$ vs. lung $46 \pm 5$ cells/HPF; $<<0.0001$ ) and in 
the Sd (liver $61 \pm 4$ vs. lung $11 \pm 1$ cells/HPF; $p<0.0001$; fig. $1 \mathrm{~b}$ ). Also in the analysis of $\mathrm{CD}_{45 \mathrm{RO}^{+}}$cells, no significant infiltration difference was noted in the Tu (liver $62 \pm 5$ vs. lung $99 \pm 43$ cells/HPF; $\mathrm{p}=0.1561$ ), whereas the cell numbers of liver samples were significantly higher in the Im (liver $272 \pm 11$ vs. lung $107 \pm 17$ cells/HPF; $p<0.0001$ ) and in the Sd (liver $78 \pm 6$ vs. lung $30 \pm 3$ cells/HPF; p < 0.0001; fig. 1c). CD20 (Tu $14 \pm 8 ; \operatorname{Im~} 14 \pm 3$; Sd $1 \pm 1$ cells/HPF; $\mathrm{p}=0.1045$ ) and $\mathrm{CD}^{+} 8^{+}$(Tu $8 \pm 3$; Im $32 \pm 3$; Sd $26 \pm 2$ cells/HPF; $\mathrm{p}<0.0001$ ) cells were only analyzed in lung samples without statistically significant differences for CD $20^{+}$ cells and significant lower numbers of $\mathrm{CD} 8^{+}$cells in the Tu compared to the Im and Sd (online suppl. fig. 1A, B). Additionally, it was noted that in lung metastases, the infiltration of $\mathrm{CD}^{+}$, $\mathrm{CD}^{+}, \mathrm{CD} 45 \mathrm{RO}^{+}$and $\mathrm{CD} 20^{+}$cells was significantly less in the distant lung tissue when compared to the Tu and Im. To test if differences in the immune infiltrates of multiple metastases in one single patient might have relevant implications on the results of this study, we analyzed CD $4^{+}$ cell numbers in 2 different lung metastases. In this comparison of the respective areas of the two metastases, we did not detect any significant differences (online suppl. fig. 4).

\section{Cellular Infiltration Pattern of Colorectal Lung Metastases Influences Patient Survival}

For survival analysis, the patients were divided into a group with a high infiltration and a group with a low infiltration by the respective cells. Cell numbers larger than the respective mean were defined as 'high', smaller as 'low'. Significantly increased patient survival was noted in patients with high $\mathrm{CD}^{+}[103 \pm 33$ vs. $37 \pm 6$ months; hazard ratio 2.91 (95\% CI 1.174.98 ); $p=0.0246$; fig. $2 \mathrm{~b}$ ] cell numbers in the Tu region compared to patients with a low infiltration by these cells. In contrast, no statistically significant survival differences based on $\mathrm{CD} 4^{+}$cell infiltration in the $\operatorname{Im}(\mathrm{p}=0.3903$; fig. $2 \mathrm{c})$ and in the $\mathrm{Sd}$ area were detected $(\mathrm{p}=$ 0.6291 ; fig. $2 d$ ). Further, the survival of patients with high $\mathrm{CD}^{+}$(Tu $\mathrm{p}=0.4359$; $\operatorname{Im} \mathrm{p}=0.8148$; $\mathrm{Sd} p=0.5402$; fig. 3), CD45RO ${ }^{+}$(Tu p = 0.5368; Im $\mathrm{p}=0.3343$; Sd $\mathrm{p}=0.8156$; fig. 4), CD20 ${ }^{+}$ ( Tu p $=0.6110 ; \mathrm{Im} \mathrm{p}=0.6475 ; \mathrm{Sd} \mathrm{p}=0.8420$; online suppl. fig. 2 ) and $\mathrm{CD} 8^{+}$cell numbers (Tu $\mathrm{P}=0.8298 ; \mathrm{Im} \mathrm{p}=0.2302 ; \mathrm{Sd} \mathrm{p}=0.2591$; online suppl. fig. 3 ) was not different from that of patients with a low infiltration by the respective cells in the 3 different sample regions analyzed.

\section{Preoperative Chemotherapy Does Not Influence Cellular Immune Infiltrates of Colorectal} Lung Metastases

A statistical analysis that compared patients receiving or not receiving preoperative chemotherapy revealed that the respective patient groups generally were comparable with regard to clinical factors. Further, the administration of preoperative chemotherapy did not influence immune cell infiltration of colorectal lung metastases. More specifically, the numbers of $\mathrm{CD}^{+}, \mathrm{CD} 20^{+}, \mathrm{CD} 45 \mathrm{RO}^{+}, \mathrm{CD} 8^{+}$and $\mathrm{CD}^{+}$cells in the $\mathrm{Tu}$, but also in the Im and in the distant lung areas were not statistically different between patients that received preoperative chemotherapy and chemotherapy-naïve patients (table 2).

\section{Discussion}

In this study, a comparative analysis of colorectal lung and liver metastases detected relevant differences in immune cell infiltrates. More specifically, colorectal liver metastases showed significantly higher numbers of infiltrating cells especially in the Im which demonstrates that in the liver the main immunological interference between host and tumor takes place in this area. This is supported by a previous study that discovered significant differences in patient survival in case of a dense infiltration by $\mathrm{CD}^{+}, \mathrm{CD} 45 \mathrm{RO}^{+}$and $\mathrm{CD}^{+}$cells in the Im [3]. In contrast to this infiltration pattern typical for the liver, the examined lung metas- 


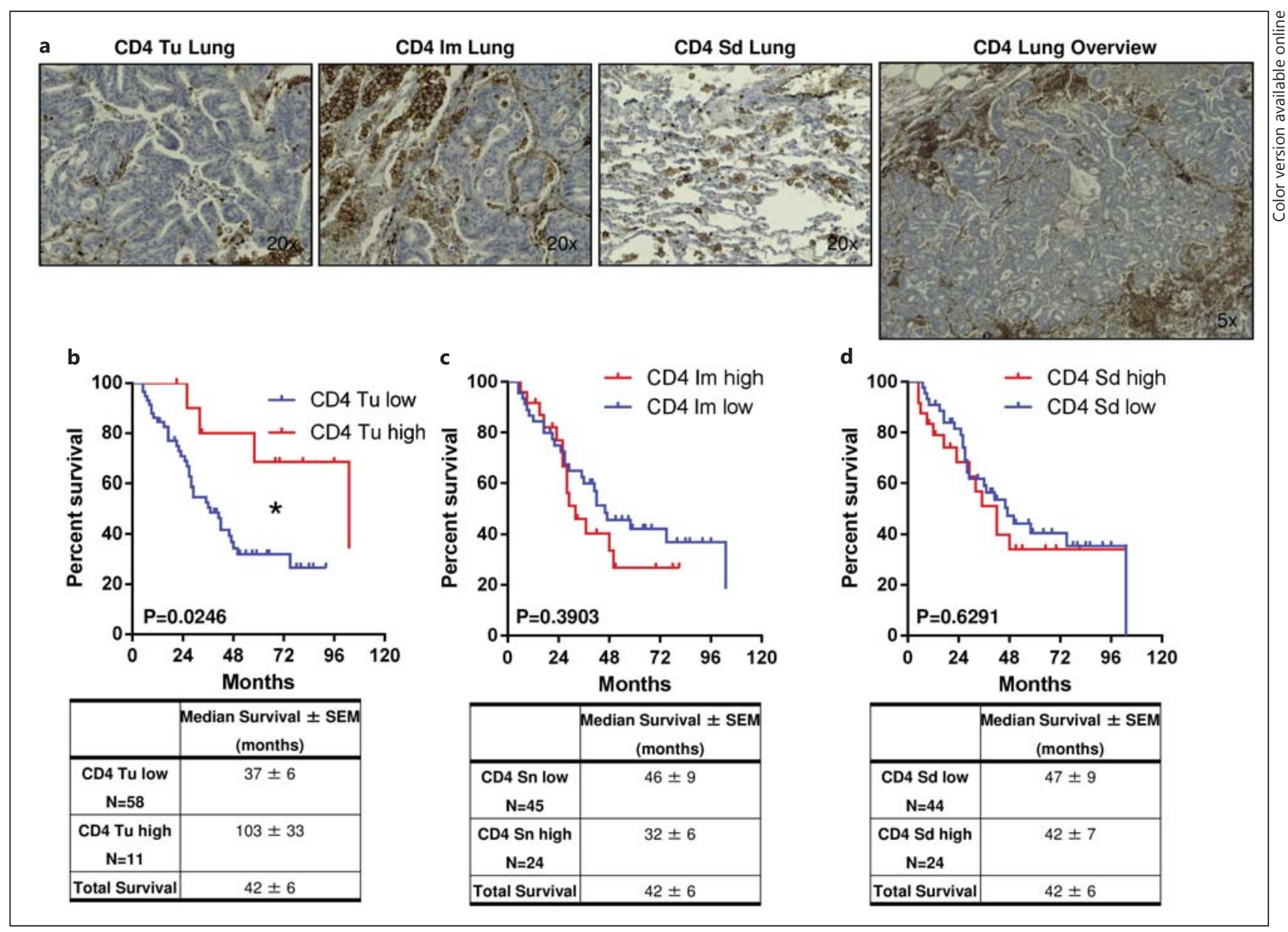

Fig. 2. Dense infiltration of $\mathrm{CD} 4^{+}$cells in the tumor is associated with increased patient survival. a Representative immunohistochemical stainings for $\mathrm{CD} 4^{+}$cells (brown; color refers to the online version only) separately for the Tu, Im and Sd. b Increased survival was noted in patients with high $\mathrm{CD} 4^{+}$cell numbers in the Tu compared to patients with a low infiltration by CD4 ${ }^{+}$cells [hazard ratio 2.91 (95\% CI 1.17-4.98); $\mathrm{p}=$ 0.0246]. c Survival of patients with high $\mathrm{CD} 4^{+}$cell numbers in the Im was not different to that of patients with a low infiltration by these cells $(\mathrm{p}=0.3903)$. $\mathbf{d}$ No statistical difference in survival was detected between patients with low and high $\mathrm{CD}^{+}{ }^{+}$cell numbers in the Sd area $(\mathrm{p}=0.6291) .{ }^{*} \mathrm{p}<0.05$.

tases showed a homogenous cell infiltration of the Tu and Im with significantly decreased cell accumulation in the distant lung tissue. This depicts that the immunological site of action in colorectal lung metastases is located in the Tu and in its Im. However, survival is associated with cell infiltration in the tumor.

To prove that this pulmonary-specific cellular immune architecture has implications for survival of patients after resection of colorectal lung metastases, a survival analysis was performed comparing patients with a 'high' and 'low' immune cell infiltration in the respective areas. Indeed, patients with a 'high' infiltration by $\mathrm{CD} 4^{+}$cells within the Tu survived significantly longer when compared to patients with a low CD4+ cell infiltration. This is in accordance with previous studies that found $\mathrm{CD}^{+}$Th1 cells infiltrating the primary colorectal carcinoma to be beneficial for long-term patient survival and that this fact can be used for risk stratification $[8,9,14,15]$. These survival differences with regard to $\mathrm{CD} 4^{+}$cell infiltration in the Tu were not detectable in the Im and in the lung periphery, which underlines the immu- 
Brunner et al.: Immune Architecture of Colorectal Lung Metastases and Implications

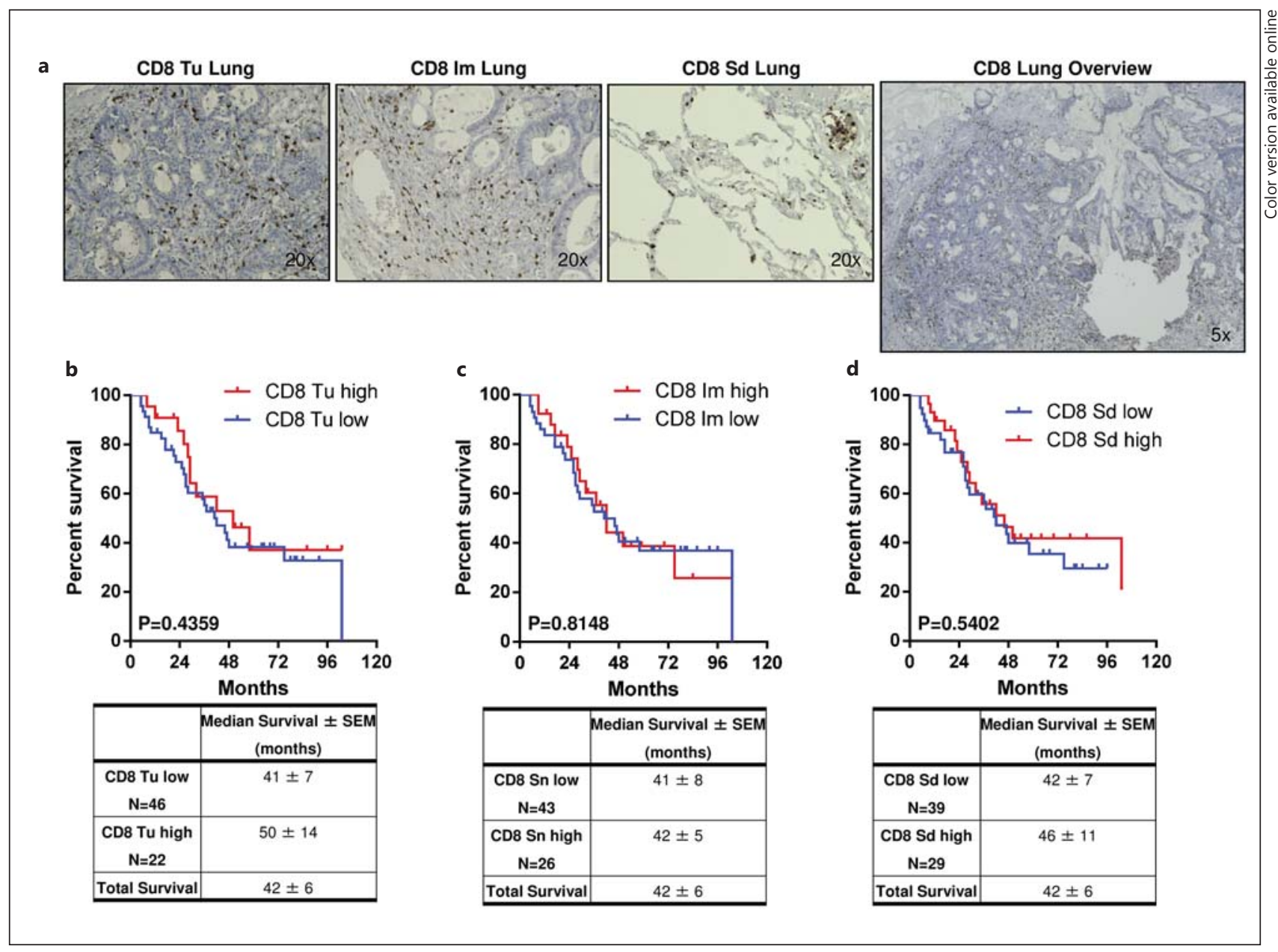

Fig. 3. Dense infiltration of $\mathrm{CD}^{+}$cells does not influence patient survival. a Representative immunohistochemical stainings for $\mathrm{CD}^{+}$cells (brown; color refers to the online version only) separately for the Tu, Im and Sd. b Survival did not differ in patients with high $\mathrm{CD}^{+}$cell numbers in the Tu compared to patients with a low infiltration by CD8 ${ }^{+}$cells $(p=0.4359)$. c Survival of patients with high CD8 ${ }^{+}$cell numbers in the Im was not different to that of patients with a low infiltration by these cells $(\mathrm{p}=0.8148)$. $\mathbf{d}$ No statistical difference in survival was detected between patients with low and high $\mathrm{CD}^{+}$cell numbers in the Sd area $(\mathrm{p}=0.5402)$.

nological importance of the Tu specifically in lung metastases. This finding is supported by a study that compared colorectal lung metastases with their primary tumor and renal cell carcinoma lung metastases. In this study, a 'high' cell infiltration of the Tu by CD8 ${ }^{+}, \mathrm{DC}^{-\mathrm{LAMP}^{+}}$ mature dendritic cells and $\mathrm{NKp} 46^{+} \mathrm{NK}$ cells was associated with a better patient survival [16]. In our study, these results could not be confirmed for $\mathrm{CD}^{+}$cells. However, the survival differences with regard to $\mathrm{CD} 4^{+}$cell infiltration in the Tu add an essential fact to the picture of immune cell architecture of colorectal lung metastases. Further, Remark et al. [16] found that the immune infiltrates of primary colorectal carcinomas and their lung metastases are similar, whereas colorectal liver metastases in our study show differences in the immunological architecture when compared to their lung metastases not only with regard to the region but also with regard to the type of cells that are responsible for survival differences.

Another important finding of this study is that preoperative chemotherapy of patients that are resected for colorectal lung metastases does not influence the immune infiltrate. This 


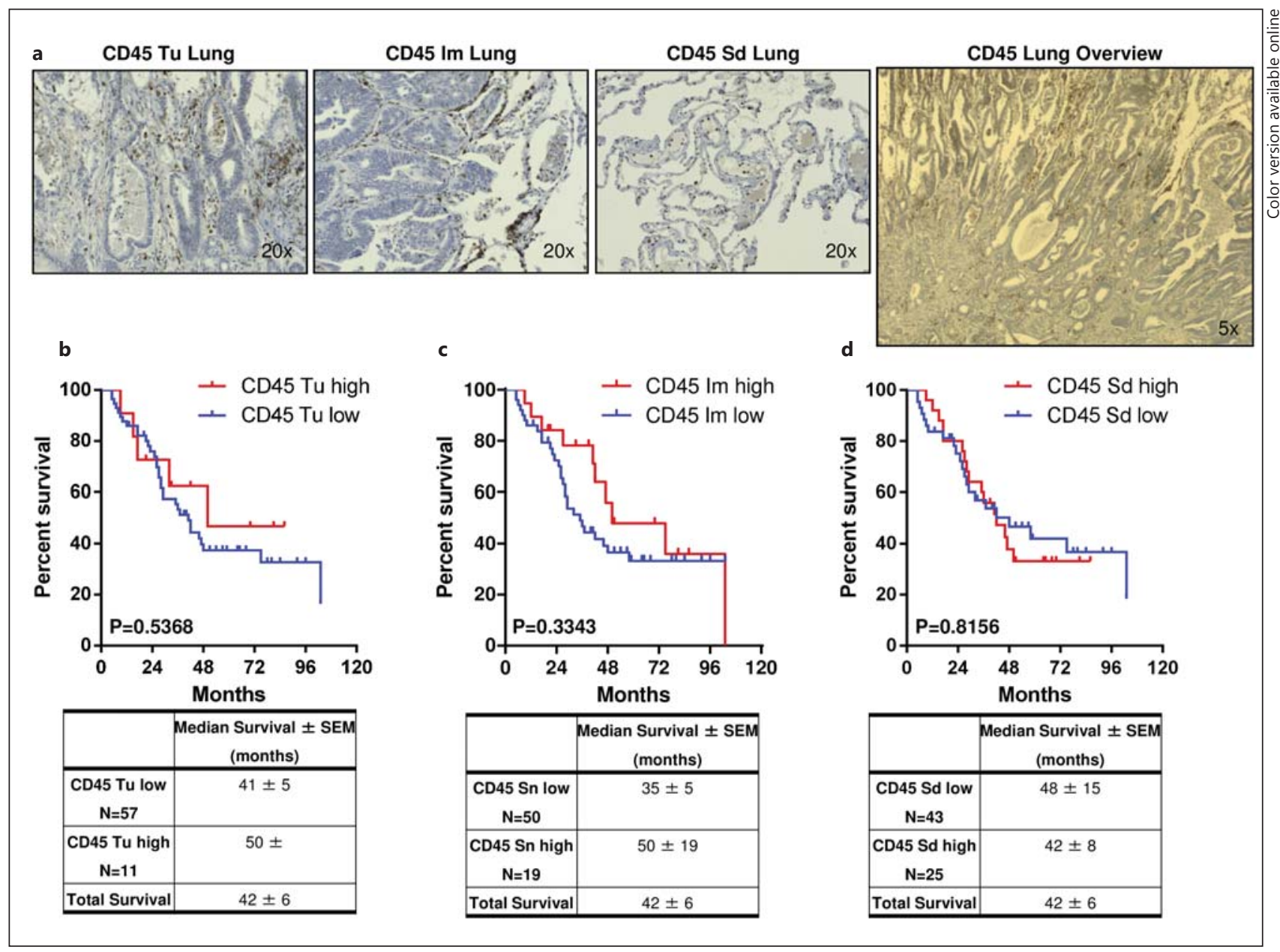

Fig. 4. Dense infiltration of $\mathrm{CD}^{2} 5 \mathrm{RO}^{+}$cells does not influence patient survival. a Representative immunohistochemical stainings for $\mathrm{CD}_{4} 5 \mathrm{RO}^{+}$cells (brown; color refers to the online version only) separately for the $\mathrm{Tu}$, Im and Sd. b Survival did not differ in patients with high $\mathrm{CD}_{4} \mathrm{RO}^{+}$cell numbers in the Tu compared to patients with a low infiltration by $\mathrm{CD}_{4} 5 \mathrm{RO}^{+}$cells $(\mathrm{p}=0.5368)$. c Survival of patients with high $\mathrm{CD}^{2} 5 \mathrm{RO}^{+}$cell numbers in the Im was not different to that of patients with a low infiltration by these cells $(\mathrm{p}=0.3343)$.

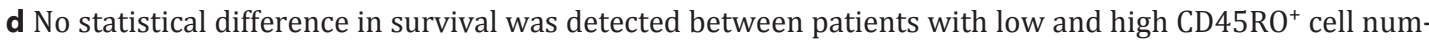
bers in the Sd area $(p=0.8156)$.

is highly relevant, since interference of chemotherapy with a beneficial immune infiltration phenotype could potentially lead to even worsened patient outcome [17]. This negative effect has been described after radiochemotherapy of esophageal cancer [18]. However, there are no reports about the influence of chemotherapy on the immune infiltrates of colorectal lung metastases so far. Generally, there are no prospective randomized controlled trials investigating the role of chemotherapy after resection of colorectal lung metastases [13]. A metaanalysis by Gonzalez et al. [19] including 25 studies and a total of 2,925 patients did not detect chemotherapy to be associated with prolonged survival after resection of colorectal lung metastases. Further, there are reports that adjuvant chemotherapy is marginally beneficial after combined resection of colorectal liver and lung metastases; however, it remains unclear if this can be extrapolated to the situation after resection of colorectal lung metastases alone $[20,21]$. 
European

Surgical

Research

Table 2. Comparison of patient characteristics between those receiving and not receiving preoperative chemotherapy

\begin{tabular}{l|l}
\hline Eur Surg Res 2016;57:186-196 \\
\hline DOI: 10.1159/000447555 & $\begin{array}{l}\text { @ 2016 S. Karger AG, Basel } \\
\text { www.karger.com/esr }\end{array}$ \\
\hline
\end{tabular}

Brunner et al.: Immune Architecture of Colorectal Lung Metastases and Implications for Patient Survival

\begin{tabular}{|c|c|c|c|c|}
\hline \multirow[t]{2}{*}{ Criteria } & & \multicolumn{3}{|c|}{ Preoperative chemotherapy } \\
\hline & & $\begin{array}{l}\text { yes } \\
(n=12)\end{array}$ & $\begin{array}{l}\text { no } \\
(\mathrm{n}=57)\end{array}$ & $\begin{array}{l}\mathrm{p} \\
\text { value }\end{array}$ \\
\hline \multirow[t]{2}{*}{ Male } & Yes & $6(8.7)$ & $18(26.1)$ & 0.223 \\
\hline & No & $6(8.7)$ & $39(56.5)$ & \\
\hline \multirow[t]{2}{*}{ Nicotine abuse } & Yes & 0 & $13(18.8)$ & 0.066 \\
\hline & No & $12(17.4)$ & $44(63.8)$ & \\
\hline \multirow[t]{2}{*}{ Pulmonary disease } & Yes & 0 & $9(13.0)$ & $0.014^{*}$ \\
\hline & No & $12(17.4)$ & $48(69.6)$ & \\
\hline \multirow{2}{*}{$\begin{array}{l}\text { R0 resection of lung } \\
\text { metastases }\end{array}$} & Yes & $11(15.9)$ & $56(81.6)$ & 0.217 \\
\hline & No & $1(1.4)$ & $1(1.4)$ & \\
\hline \multirow[t]{2}{*}{ Lymphadenectomy } & Yes & $7(10.1)$ & $41(59.4)$ & 0.352 \\
\hline & No & $5(7.2)$ & $16(23.2)$ & \\
\hline \multirow{2}{*}{$\begin{array}{l}\text { Pulmonary lymph nodes } \\
\text { positive (out of } \\
\text { lymphadenectomy) }^{\mathrm{a}}\end{array}$} & Yes & $1(2.1)$ & $7(14.6)$ & 0.855 \\
\hline & No & $6(12.5)$ & $34(70.8)$ & \\
\hline \multirow{2}{*}{$\begin{array}{l}\text { Primary tumor colon/ } \\
\text { rectum }\end{array}$} & Colon & $7(10.1)$ & $16(23.2)$ & 0.124 \\
\hline & Rectum & $5(7.2)$ & $41(59.4)$ & \\
\hline \multirow{2}{*}{$\begin{array}{l}\text { Primary tumor lymph node } \\
\text { metastases }\end{array}$} & Yes & $5(7.2)$ & 31 (44.9) & 0.423 \\
\hline & No & $7(10.1)$ & $26(37.7)$ & \\
\hline \multirow[t]{2}{*}{ Primary tumor $\mathrm{R}^{\mathrm{b}}$} & Yes & $9(13.0)$ & $45(65.2)$ & 0.338 \\
\hline & No & $1(1.4)$ & $4(5.8)$ & \\
\hline \multirow[t]{2}{*}{$\mathrm{CD} 4 \mathrm{Sd}^{\mathrm{c}}$} & High & $5(7.4)$ & $19(27.9)$ & 0.611 \\
\hline & Low & $7(10.3)$ & $37(54.4)$ & \\
\hline \multirow[t]{2}{*}{ CD4 Im } & High & $4(5.8)$ & $20(29.0)$ & 0.908 \\
\hline & Low & $8(11.6)$ & 37 (53.6) & \\
\hline \multirow[t]{2}{*}{$\mathrm{CD} 4 \mathrm{Tu}$} & High & $3(4.3)$ & $8(11.6)$ & 0.346 \\
\hline & Low & $9(13.0)$ & $49(71.0)$ & \\
\hline \multirow[t]{2}{*}{ CD45R0 Sd } & High & $7(10.3)$ & $18(26.5)$ & 0.088 \\
\hline & Low & $5(7.4)$ & 38 (55.9) & \\
\hline \multirow[t]{2}{*}{ CD45R0 Im } & High & $4(5.8)$ & 15 (21.7) & 0.621 \\
\hline & Low & 8 (11.6) & $42(60.9)$ & \\
\hline \multirow[t]{2}{*}{$\mathrm{CD} 45 \mathrm{RO} \mathrm{Tu}$} & High & $2(2.9)$ & $9(13.2)$ & 0.959 \\
\hline & Low & $10(14.7)$ & $47(69.1)$ & \\
\hline \multirow[t]{2}{*}{$\mathrm{CD} 20 \mathrm{Sd}^{\mathrm{c}}$} & High & $2(2.9)$ & $11(16.2)$ & 0.812 \\
\hline & Low & $10(14.7)$ & $45(66.2)$ & \\
\hline \multirow[t]{2}{*}{ CD20 $\operatorname{Im}^{\mathrm{c}}$} & High & 0 & $12(17.6)$ & 0.077 \\
\hline & Low & $12(17.6)$ & $44(64.7)$ & \\
\hline \multirow[t]{2}{*}{$\overline{\mathrm{CD}} 20 \mathrm{Tu}^{\mathrm{c}}$} & High & 0 & $5(7.4)$ & 0.282 \\
\hline & Low & $12(17.6)$ & $51(75.0)$ & \\
\hline \multirow[t]{2}{*}{$\overline{C D} 8 \mathrm{Sd}^{\mathrm{c}}$} & High & $5(7.4)$ & $24(35.3)$ & 0.940 \\
\hline & Low & $7(10.3)$ & $32(47.1)$ & \\
\hline \multirow[t]{2}{*}{ CD8 Im } & High & $4(10.1)$ & $22(31.9)$ & 0.732 \\
\hline & Low & 8 (11.6) & $35(50.7)$ & \\
\hline$\overline{\mathrm{CD} 8 \mathrm{Tu}^{\mathrm{c}}}$ & High & $2(2.9)$ & $20(29.4)$ & 0.201 \\
\hline & Low & $10(14.7)$ & $36(52.9)$ & \\
\hline CD68 Sd & High & $4(6.0)$ & $21(31.3)$ & 0.753 \\
\hline & Low & $8(11.9)$ & $34(50.7)$ & \\
\hline CD68 Im & High & $4(5.8)$ & $25(36.2)$ & 0.502 \\
\hline & Low & $8(11.6)$ & $32(46.4)$ & \\
\hline$\overline{\mathrm{CD} 68 \mathrm{Tu}^{\mathrm{c}}}$ & High & $2(2.9)$ & $15(22.1)$ & 0.463 \\
\hline & Low & $10(14.7)$ & $41(60.3)$ & \\
\hline
\end{tabular}

Data are presented as n (\%). ${ }^{\text {a }}$ Only performed in 48 patients. ${ }^{\mathrm{b}}$ Some histology reports of primary tumors were incomplete. ${ }^{\mathrm{c}}$ Some stainings (1-2 patients) were not analyzable. 
Other factors like time of occurrence and number of pulmonary metastases that significantly influenced survival in a previous study had no implications on survival in our study [22]. This most likely is due to the fact that this huge study with 5,206 patients investigated lung metastases of sarcomas, melanomas, germ cells tumors and only to a minor part epithelial primary tumors that were not further specified with regard to the number of colorectal carcinomas [22]. This further underlines the importance of our study, which selectively analyzes the survival of colorectal carcinoma lung metastases.

The retrospective nature, the limited patient number and the lack of a confirmation of the results in an independent patient cohort are possible limitations of this study. However, this is the first study to compare the immune architecture of colorectal liver and lung metastases.

In conclusion, the immune architecture of colorectal liver and lung metastases shows differences, with a higher immunological importance of the Tu in lung metastases. More specifically, a 'high' infiltration of this Tu of pulmonary metastases by CD4 ${ }^{+}$cells is associated with prolonged patient survival. Further, preoperative chemotherapy does not influence the local immune infiltrate.

\section{Acknowledgements}

This study was supported by the University of Regensburg.

\section{Disclosure Statement}

The authors disclose no conflicts of interest.

\section{References}

1 Edge SB, Compton CC: The American Joint Committee on Cancer: the 7th edition of the AJCC cancer staging manual and the future of TNM. Ann Surg Oncol 2010;17:1471-1474.

2 Bindea G, Mlecnik B, Fridman WH, Galon J: The prognostic impact of anti-cancer immune response: a novel classification of cancer patients. Semin Immunopathol 2011;33:335-340.

3 Brunner SM, Kesselring R, Rubner C, Martin M, Jeiter T, Boerner T, et al: Prognosis according to histochemical analysis of liver metastases removed at liver resection. Br J Surg 2014;101:1681-1691.

4 Camus M, Tosolini M, Mlecnik B, Pages F, Kirilovsky A, Berger A, et al: Coordination of intratumoral immune reaction and human colorectal cancer recurrence. Cancer Res 2009;69:2685-2693.

5 Fridman WH, Galon J, Dieu-Nosjean MC, Cremer I, Fisson S, Damotte D, et al: Immune infiltration in human cancer: prognostic significance and disease control. Curr Top Microbiol Immunol 2011;344:1-24.

6 Galon J, Costes A, Sanchez-Cabo F, Kirilovsky A, Mlecnik B, Lagorce-Pages C, et al: Type, density, and location of immune cells within human colorectal tumors predict clinical outcome. Science 2006;313:1960-1964.

7 Pages F, Berger A, Camus M, Sanchez-Cabo F, Costes A, Molidor R, et al: Effector memory T cells, early metastasis, and survival in colorectal cancer. N Engl J Med 2005;353:2654-2666.

8 Pages F, Galon J, Dieu-Nosjean MC, Tartour E, Sautes-Fridman C, Fridman WH: Immune infiltration in human tumors: a prognostic factor that should not be ignored. Oncogene 2010;29:1093-1102.

9 Tosolini M, Kirilovsky A, Mlecnik B, Fredriksen T, Mauger S, Bindea G, et al: Clinical impact of different classes of infiltrating T cytotoxic and helper cells (Th1, th2, treg, th17) in patients with colorectal cancer. Cancer Res 2011;71:1263-1271.

10 Galon J, Pages F, Marincola FM, Thurin M, Trinchieri G, Fox BA, et al: The immune score as a new possible approach for the classification of cancer. J Transl Med 2012;10:1.

11 Dave RV, Pathak S, White AD, Hidalgo E, Prasad KR, Lodge JP, et al: Outcome after liver resection in patients presenting with simultaneous hepatopulmonary colorectal metastases. Br J Surg 2015;102:261-268.

12 Qiu M, Hu J, Yang D, Cosgrove DP, Xu R: Pattern of distant metastases in colorectal cancer: a SEER based study. Oncotarget 2015;6:38658-38666.

13 Treasure T, Milosevic M, Fiorentino F, Macbeth F: Pulmonary metastasectomy: what is the practice and where is the evidence for effectiveness? Thorax 2014;69:946-949.

14 Galon J, Franck P, Marincola FM, Angell HK, Thurin M, Lugli A, et al: Cancer classification using the Immunoscore: a worldwide task force. J Transl Med 2012;10:205. 
15 Pages F, Kirilovsky A, Mlecnik B, Asslaber M, Tosolini M, Bindea G, et al: In situ cytotoxic and memory T cells predict outcome in patients with early-stage colorectal cancer. J Clin Oncol 2009;27:5944-5951.

16 Remark R, Alifano M, Cremer I, Lupo A, Dieu-Nosjean MC, Riquet M, et al: Characteristics and clinical impacts of the immune environments in colorectal and renal cell carcinoma lung metastases: influence of tumor origin. Clin Cancer Res 2013;19:4079-4091.

17 Stoll G, Bindea G, Mlecnik B, Galon J, Zitvogel L, Kroemer G: Meta-analysis of organ-specific differences in the structure of the immune infiltrate in major malignancies. Oncotarget 2015;6:11894-11909.

18 Vacchelli E, Semeraro M, Enot DP, Chaba K, Poirier Colame V, Dartigues P, et al: Negative prognostic impact of regulatory $\mathrm{T}$ cell infiltration in surgically resected esophageal cancer post-radiochemotherapy. Oncotarget 2015;6:20840-20850.

19 Gonzalez M, Poncet A, Combescure C, Robert J, Ris HB, Gervaz P: Risk factors for survival after lung metastasectomy in colorectal cancer patients: a systematic review and meta-analysis. Ann Surg Oncol 2013;20:572579.

20 Brandi G, Derenzini E, Falcone A, Masi G, Loupakis F, Pietrabissa A, et al: Adjuvant systemic chemotherapy after putative curative resection of colorectal liver and lung metastases. Clin Colorectal Cancer 2013;12:188194.

21 Mitry E, Fields AL, Bleiberg H, Labianca R, Portier G, Tu D, et al: Adjuvant chemotherapy after potentially curative resection of metastases from colorectal cancer: a pooled analysis of two randomized trials. J Clin Oncol 2008;26:4906-4911.

22 Pastorino U, Buyse M, Friedel G, Ginsberg RJ, Girard P, Goldstraw P, et al: Long-term results of lung metastasectomy: prognostic analyses based on 5,206 cases. J Thorac Cardiovasc Surg 1997;113:37-49. 